\title{
UNCLASSFIIED
}

Photostat Price $\$$
Microfilm Price $\$$
Availablè from the
Office of Technical Services
Department of Commerce
Washington 25, D. C.

Contract No. Wh $74.05=\mathrm{Eng}=4.8 \mathrm{~B}$ $(1)-265)$

Soction B

00000

\section{The Solvent Extraction of Pu(IV) by Tripluoroacetylacetone}

H. W. Crandall, Jo R. Thomas, J. C. ReLd

January 15,1845
CEASSIFICATION CANCELLED DATE FEB 191957 Q For The Atomio Energy Commission - Ho h Manala Chief, Deciassification Branch

\author{
- Table or Contents \\ I. The Solvent Extraction of Pu(IV) by \\ Tritluoroacetylacetone (MFA) \\ II. The Behavior of TFA in vater Solution
}

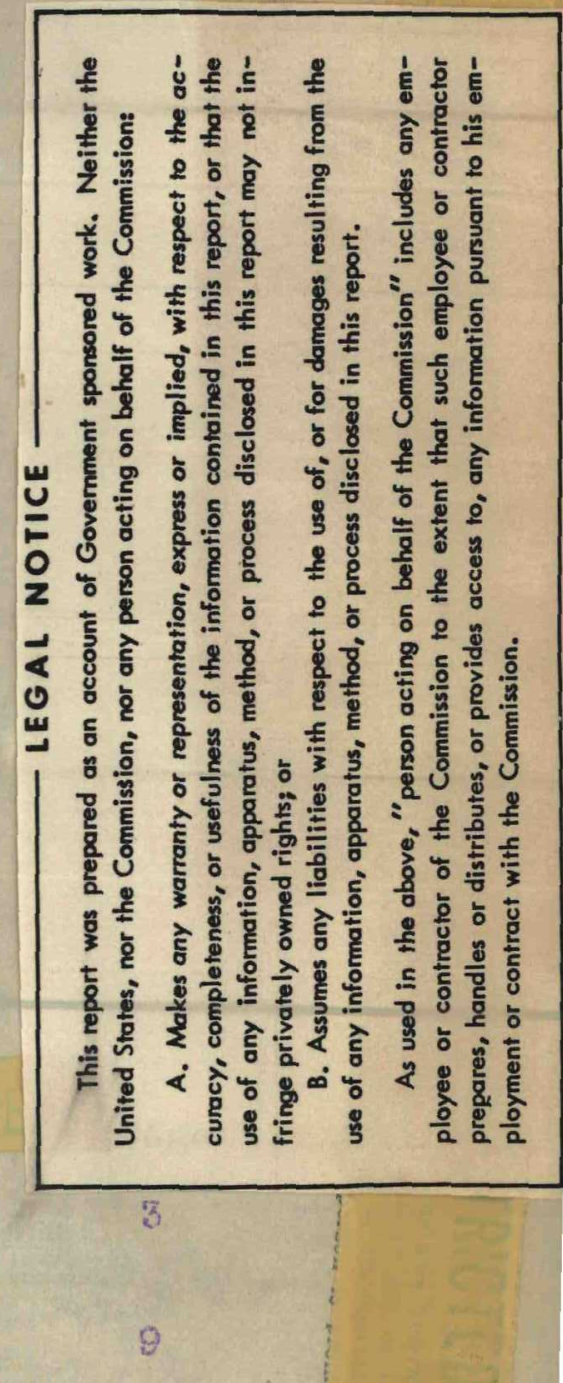

Report Rece1ved: January 26, 1945; HAvre Recolved: Jamuary 26, 1945 Issuod:

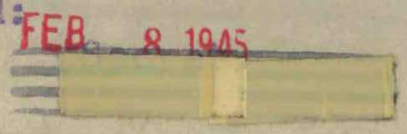

$64 / 2$

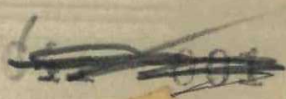




\section{DISCLAIMER}

This report was prepared as an account of work sponsored by an agency of the United States Government. Neither the United States Government nor any agency Thereof, nor any of their employees, makes any warranty, express or implied, or assumes any legal liability or responsibility for the accuracy, completeness, or usefulness of any information, apparatus, product, or process disclosed, or represents that its use would not infringe privately owned rights. Reference herein to any specific commercial product, process, or service by trade name, trademark, manufacturer, or otherwise does not necessarily constitute or imply its endorsement, recommendation, or favoring by the United States Government or any agency thereof. The views and opinions of authors expressed herein do not necessarily state or reflect those of the United States Government or any agency thereof. 


\section{DISCLAIMER}

Portions of this document may be illegible in electronic image products. Images are produced from the best available original document. 


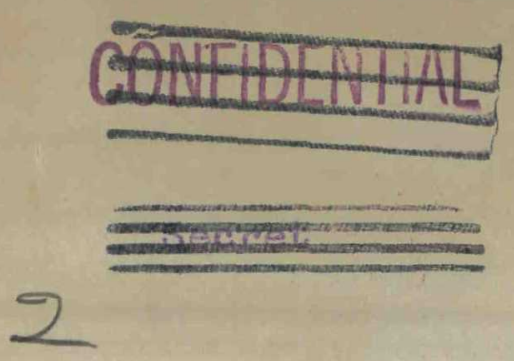

Abstracts

I. The Solvent Extraction of Pu(IV) by Trifluorow aceiglacetone (TPA).

Certain variabies of the extraction step of the proposed solvent extraction process using PFA have been investigated. The extraction of Fu(IV) by TYA In benzene was found to vary with the time of shalring of the benzene and aqueous lajers. Instially the extraction com effleient into benzene xose to a maximum within one or two minutes after which it rapialy fell off to $1 / 10$ to $1 / 5$ of jts peak value. It was established that the drop from this peak value was due to some change in the TFA and not of the Pu(IV). After $15-20$ minutes of shairing, the extraction coefficient is relatively constant except that a very slow reduction of Pu(IV) to Pu(III) was observed. Reproducible values of the extraction cow efflcient were determined under a variety of conditions as a guide to the selection of favorable extraction con ditions.

II. The Behavior of THA in water Solutions.

The hyarolysis of THA in alkaline solution Is described. In acla solution the TFA appears to set up a reversible equ111brjum with some other substance which has not been identified.

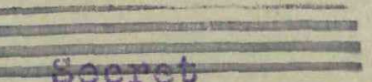

inceret 


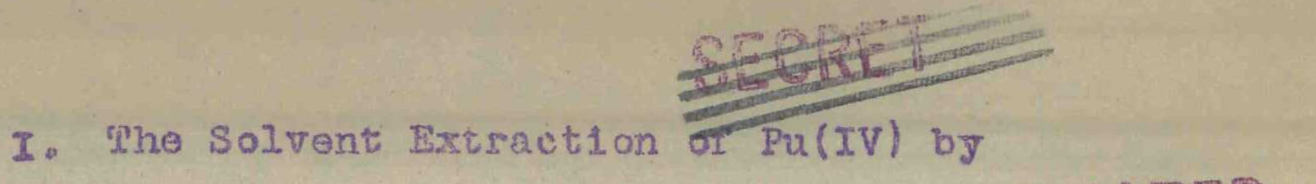

Trifluoro-acetylacetone $(\mathrm{I}, \mathrm{F} \cdot \mathrm{A} \cdot)$

H. W. Crandal1 and J. R. Thomas

In CN-2486 Calvin proposed a 11quid-liquld extraction method for use as an extraction decontamination process for plutonlum. Lhe extraction procedure conslsts of selectively ex= tracting Pu(IV) as a non-1onlzed cholate compound of PFA which 1. soluble in organjc solvents 1 mmiscible with water. In $\mathrm{CW}_{\mathrm{W}} \mathrm{2} 486$ preliminary rosults were presented with respect to the oxtracting power of IHA in benzene for Fu(IV) and the dependence of the extraction coefficlent $E$ upon the acidity of the water layer and the TFA concentration in the benzene layer. Further extraction coefflcients wero determined in UNHenra $\mathrm{SO}_{4}$ solutions.

Since these prelininary experiments were reported it has been observed that the extraction coefflclent is markedly dependent upon the time of contact, $i . \theta$. time of vigorous shaking of tho aquoous and organle solvent lajors. In Figure 1. a plot of $\mathrm{E}$ agelnst time of shaking is shown. The shaking was. 300 v1 brations per minute with $1 / 2$ inch amplitude on a mechanical shaker.

Tho curves shown 1n If 1 gure 1 may bo separated into three components. The inltial rapid rise to the peak may be interpreter as the formation of the Pu(IV) chelate compound and its diffusion into tho benzene. The rapid drop from the peak way be interproted as the setting up of some moderately rapld equilibrlum which is complete at the break of the curve. The 81 ght slope of the curves at longer times is due to somo Blower procsss different from thos determining the shape of the curves at short times of shaking.

To ascertaln whether the change responsible for the rapid drop from the peak Is due to the TFA or to some change in the na ture of the plutonlum 1tiself the following exporiment was per Iormed. A phase consisting of THA In benzene was shaken with an aqueous phase 0.5 in in $\mathrm{HNO}_{3}$ for approximately threo hours before any plutonlum was added. At tho end of the shaking period Pu(IV) tracer was added and the extraction coefficient determined after sheling for one minute. This result is to be compaxed with the value of the extraction coefficlent obtalned in a separate experinent with 30 seconds shaking of a 0.5 is nitwic acid solution contalnfng Pu(IV) in the presence of a fresh ITA benzeno layer. the results are shown in Table 1. All experiments performed wers cone with volums of $30 \mathrm{cc}$ benzene layer and 20 ce aqueous layer.

$E=\frac{(P u(I V) \beta i}{\text { (Purv })}$ the ratio of the concentrations of plutonium in 64

the benzane layer divided by the concentration of plutonium in

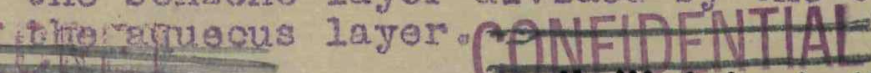




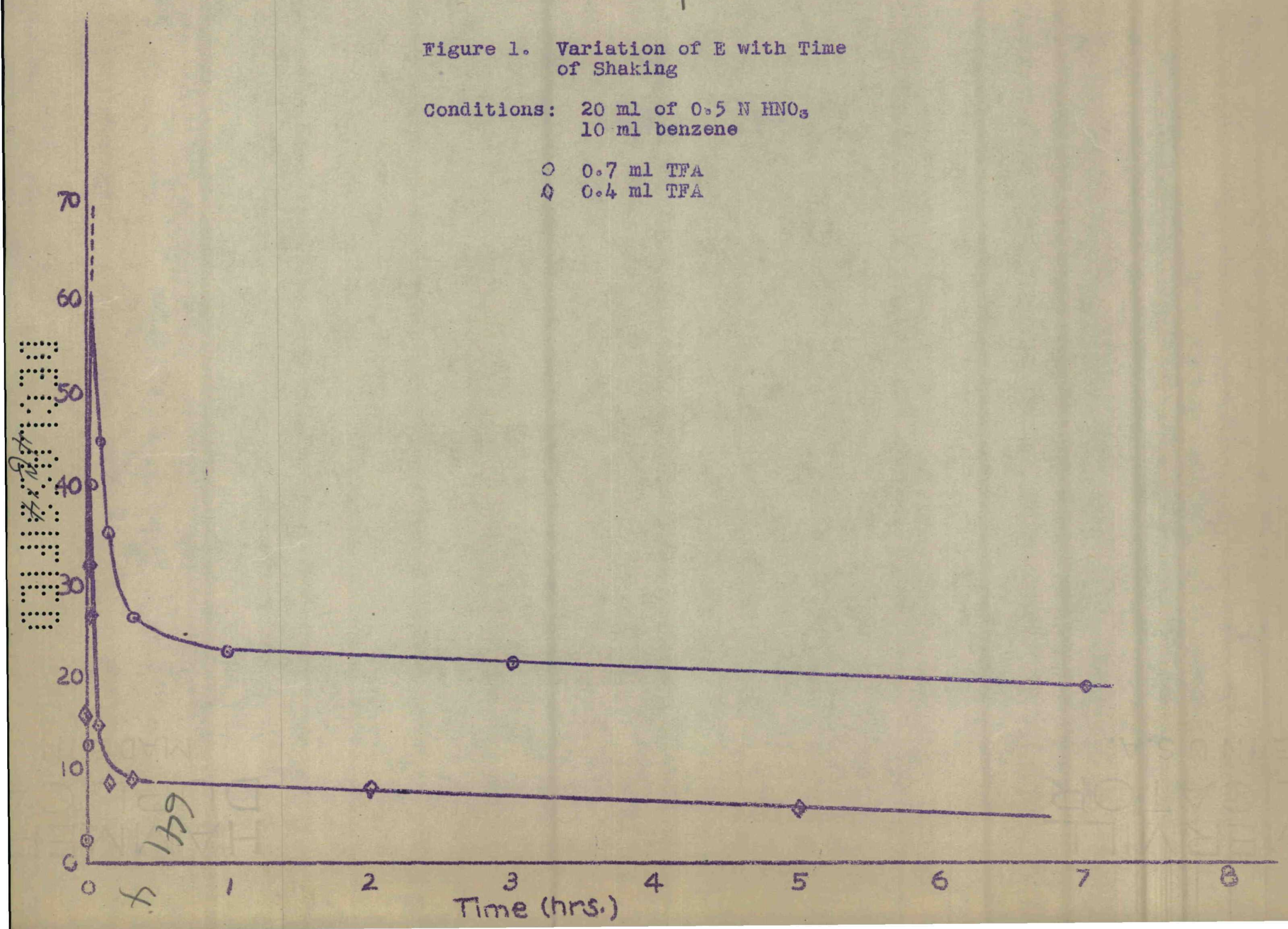




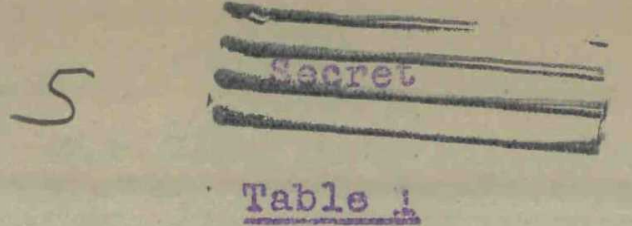

The Efrect of Shaking on the Dxtracting Power of ITA for Pu(IV)
Conditions:
$10 \mathrm{ml}$ benzene layer
$20 \mathrm{ml}$ aqueous Iayer, $0.5 \mathrm{H} \mathrm{HNO}_{3}$

\begin{tabular}{|c|c|c|c|c|c|}
\hline & inporiment & :12 I IRA & $\begin{array}{l}\text { Time of shaking } \\
\text { In absence of Pu }\end{array}$ & $\begin{array}{l}\text { Inire of shaking } \\
\text { In presence of } \mathrm{Pu}\end{array}$ & $\mathrm{E}$ \\
\hline & $I$ & 0.2 & 0 & $\therefore 30 \mathrm{sec}$. & 8.0 \\
\hline & $I \pi$ & 0.2 & . 3 hrs. & $\therefore 1 \mathrm{~min}=$ & 0.1 \\
\hline \multirow[t]{2}{*}{$I I$} & cont $\mathrm{C}$ & $\begin{array}{l}0.2 \\
\text { Adत'I }\end{array}$ & No Additional. & $\begin{array}{l}\text { I mino } \\
\text { after eresh } \\
\text { PFA was added }\end{array}$ & 2.3 \\
\hline & & & & $\begin{array}{l}3 \text { mine } \\
\text { after fresh } \\
\text { PFA was adned }\end{array}$ & 1.1 \\
\hline
\end{tabular}

To the same benzene layer that extracted $\mathrm{Pu}$ (IV) relatively poorly (the second experiment of Table 1), a fresh portion of LFA was added and the layers wero shaken for one minute and the ex traction coefficlent measured. The layers were shaken for two mine utes more and the extraction coefflclent was again determined.

As may be seen from the results shown in Iable 1 , the extracting efflchency of the TEA was greatly reduced by the prelimino ary treatment of shaking, but the plutonium was in an extractablo condition since the adiltion of Iresh TrFA caused the extraction cow offlclent to increase by a large factor. The fact that the ex= traction coofficient falls off with two minutes of further shaking of the layers after the adiltion of the fresh TFA indicates that it is again falling off from lta peak value.

It was suggested that 1mpurit1es in the cormerc1al benzene used were causing the change in the extracting power of the TFA. Highly purlfled, thiophene free bonzene was substituted for the cumnerclal benzere in an experiment dupllosting one of those shown in Figure 1. No change in the shape of the curve was noted. To test the effect of the nitric sc1d on the extracting power of I'FA, a duplicats experiment was performed substituting hydrochloric acid for nitric acid. No signiflcant difference in the behavior of the extraction coefficlent with time of shaking was observed.

In order to dotermine in which phase the change in the character of the TFA was occurring experiments IV and $V$ were periformed. In experiment IV TFA was allowed to stand in $0.5 \mathrm{M}$ nltric acld overnight after which benzene and Pu(IV) tracer were 


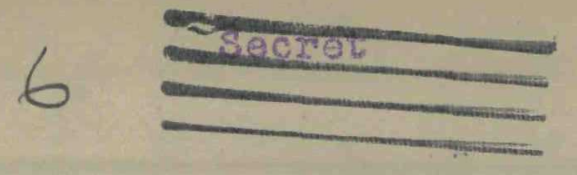

added and the extraction coefflclent of the Pu(IV) was determined. In experlment V IIFA was allowed to stand overnlght in benzene arter which $0.5 \mathrm{HI}$ nitric and $\mathrm{Pu}(\mathrm{IV})$ tracer wore added and the extraction coefflelent of the Pu(IV) was determined. The results appear in rable 2.

\section{$\underline{\text { Table } 2}$}

The Effect of Standing in N1tric

Actd and Benzeno on the Extracting Power of IFA

Conritions: $10 \mathrm{ml}$ benzene

$20 \mathrm{ml} 0.5$ ill $\mathrm{HNO}_{3}$

\begin{tabular}{|c|c|c|c|c|c|c|}
\hline Experiment & MIFA & TImo & TFA $\operatorname{In}$ & Solution & $\begin{array}{l}\text { Time of shak- } \\
\text { Ing after Ad- } \\
\text { dition of } \\
\text { Pu(IV) }\end{array}$ & $E$ \\
\hline IV & 0.20 & 12 & hours & $(\operatorname{ac} 1 d)$ & 30 sec. & 0.05 \\
\hline v & 0.20 & 12 & hours & (benzene) & 30 sec. & 8.0 \\
\hline
\end{tabular}

The results indlcate that IFA undargoes some change upon standing in the acid solution which results in a large drop in tho extracting power of the IFA. The standing in benzene had no of foct upon the extracting power of the IFA. This change 1. bel1eved to bo the factor causing the rapla drop of the extraction coefflcient From 1ts peak valuo vith lncroasing shaking timo as 11lustrated by the $s \theta$ and region ui the curves shown in Flgure 1.

The thira region of the sque curves is epparently a slow reduction of plutonium to the t3 oxidation state. This was first sispected Pron the following experdnente. Plutonium, initialiy In the th oxidation state, was allowed to remaln in the PFA-benzeneacld systom for a shaking pertod of $10-12$ hours. At the end of that time the fu distribution vas dotermined. Immediately there after a fresh 1ncrenent of IFA was added to the benzono and the now plutonium distribution was determired. After this a new increment of Iu(IV) activity was added and the resulting distribution was determinod. The results are 11 stod in Table 3.

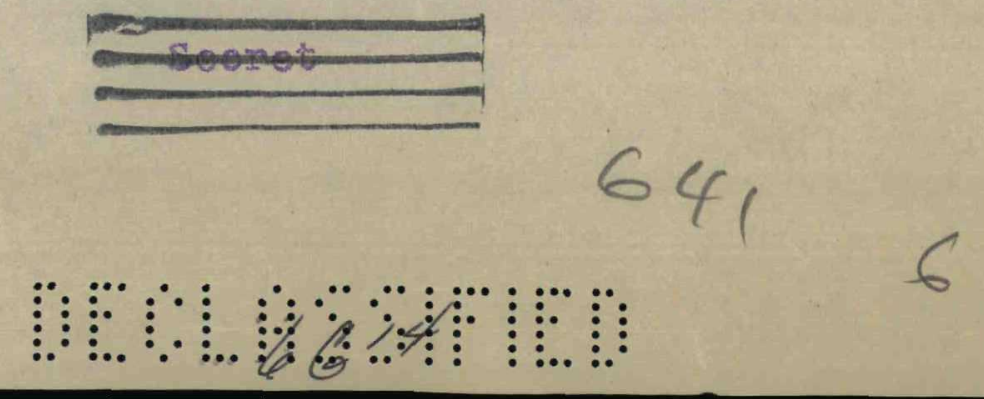




\section{Table 3}

Evidence of Fioduction of Pu(IV) by

TFA.

CondLtions: $10 \mathrm{ml}$ benzene

$20 \mathrm{mll} 0.5 \mathrm{M} \mathrm{HNO}$

\begin{tabular}{|c|c|c|c|}
\hline Experlmental conditions & MIEA & IIme of Shatring & E \\
\hline sonite & 0.2 & $10-12$ hours & 0.1 \\
\hline Frosh TFA added. & 0.4 & 1 min. & 2.5 \\
\hline Frosh Pu(IV) added & 0.4 & $2 \min$. & 6.7 \\
\hline
\end{tabular}

Frora the results it appears that the Pu(IV) was changed after the 10-12 hour shaking so that 1t was not as extractable as the Presh Pu(IV) that was added. Reduction of plutonium to the +3 oxidation state is the simplest explanation of these results.

A further experiment performed by $W$. H. Reas conclusively showed that IHA, its decomposition product: or equlilbrium products can reduce Pu(IV) to Pu(III). Reas measured the lines In the absorption spectrum of Pu(IV) in a 0.5 li nitric acld solu= tion with one mili11ter of IFA in $10 \mathrm{ml}$ of solution. Tho spectrum was alfferent from the spectrum of Pu(IV) in 0.5 M nitric acid alono. The difference was belleved to bo due to the formation of some com plex 1 on of Pu(IV) with TFA or one of 1ts decomposition or equi11urium products. Aftor standing for fivo days the spectrum appeared about the same. However, after two weeks the 3 pectrum corrospondod to that of Pu(III) in nitric ac1d. While this ovidence proves that reduction occurs, none of the exporiments performed to date glve any quantitative measure of the rate of reduction ex= cept to show that it is slow relative to the other processes involved. in the systems that have been investigated. The rate of reduction of plutonlum as measured by the slopes in the third region of the curves in Figure 1 appears to vary roughly with the amount of plutonium in the water layer and one measurement in $0.5 \mathrm{M}$ nitric acld where the extrgction coeff1cient was 5 showed 12.8 percent reduction in one hour of shaking. The rate of reduction of Pu(IV) is undergolng further atudy at the present time.

After it became apparent that the T F A was involved in a reversible equilibrium (from the work of Reld reported in Section II of this report) the vaxiation of the extraction coefflcient with HNO3, THA, UNH, and $\mathrm{Na}_{2} \mathrm{SO}_{4}$ concentrations was studied. The samples were 211 shaken for $1=1 / 2$ hours which allowed ample time for the $1 \mathrm{FA}$
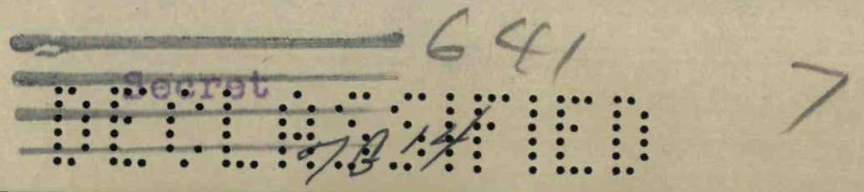


\section{8}

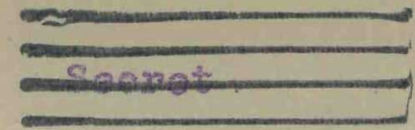

oquilibrium to be established. To eliminate any possiblo offect of reduction, the $P u(I V)$ activity was always adCed after the $I-I / 2$ hours of shaklng and the moasuroment wes mede imnediately follow Ing 1 ts addition. The results are shown in Table 4 . Tach single result represents the average of at loast two duplicate determinations. The duplicate results reproduced each other within ten percent.

\section{Table 4}

Variation of E with Extraction Variables

Cond1t1ong: $10 \mathrm{ml}$ benzere

$20 \mathrm{ml}$ aqueous layer

\begin{tabular}{|c|c|c|c|c|c|}
\hline DII INA & $\begin{array}{l}\mathrm{mil}_{3} \\
\mathrm{~mol} \mathrm{es} / \mathrm{I}\end{array}$ & $\begin{array}{l}\mathrm{Na}_{2} 50,4 \\
\mathrm{moles} / 1\end{array}$ & $\begin{array}{c}002(N)_{3} / 2 \\
m o l e s / 1\end{array}$ & $\begin{array}{l}\mathrm{HaN}_{3} \\
\mathrm{moles} / 1\end{array}$ & W \\
\hline $\begin{array}{l}0.70 \\
0.50 \\
0.80 \\
0.30 \\
0.20 \\
\end{array}$ & $\begin{array}{l}0.50 \\
0.50 \\
0.50 \\
0.50 \\
0.50 \\
\end{array}$ & & & & $\begin{array}{c}22=20 \\
11.5 \\
5.6 \\
2.9 \\
0.3 \\
\end{array}$ \\
\hline $\begin{array}{l}0.30 \\
0.20 \\
0.10 \\
\end{array}$ & $\begin{array}{l}0.25 \\
0.25 \\
0.25 \\
\end{array}$ & & & & $\begin{array}{c}21.23 \\
8.5 \\
0.92 \\
\end{array}$ \\
\hline $\begin{array}{l}0.30 \\
0.30 \\
\end{array}$ & $\begin{array}{l}0.75 \\
1.00 \\
\end{array}$ & & & & $\begin{array}{l}0.51 \\
0.25 \\
\end{array}$ \\
\hline $\begin{array}{l}0.30 \\
0.30 \\
0.30 \\
\end{array}$ & $\begin{array}{l}0.638 \\
0.334 \\
0.268 \\
\end{array}$ & $\begin{array}{l}0.5 \\
0.1 \\
0.02\end{array}$ & & & $\begin{array}{l}0.018 \\
0.075 \\
0.18 \\
\end{array}$ \\
\hline $\begin{array}{l}0.30 \\
0.30 \\
0.30 \\
\end{array}$ & $\begin{array}{l}0.50 \\
0.50 \\
0.50 \\
\end{array}$ & & $\begin{array}{l}0.8 \\
0.5 \\
0.1 \\
\end{array}$ & & $\begin{array}{l}0.46 \\
0.84 \\
2.2 \\
\end{array}$ \\
\hline $\begin{array}{l}0.3 \\
0.3 \\
\end{array}$ & $\begin{array}{l}0.50 \\
0.50 \\
\end{array}$ & $\begin{array}{l}0.1 \\
0.5 \\
\end{array}$ & $\begin{array}{l}0.8 \\
0.8 \\
\end{array}$ & & $\begin{array}{l}0.27 \\
0.081 \\
\end{array}$ \\
\hline 0.3 & 0.50 & & & 1.6 & 0.98 \\
\hline
\end{tabular}

* When $\mathrm{Na}_{2} \mathrm{SO}_{4}$ was added the Iree Ht concentration was adjugted to be 0.25 Ii in each case and the calculated free sulfate ion con contration was as follows:

$0.50 \mathrm{M} \mathrm{Na}_{2} \mathrm{SO}_{4} \quad 0.114 \mathrm{M} \mathrm{SO}_{4}=$

$0.10 \mathrm{M} \mathrm{Na}_{\mathrm{SO}} \mathrm{SO}_{4} \quad 0.017 \mathrm{H} \mathrm{\textrm {SO } _ { 4 }}=$

$\begin{array}{lll}0.02 \mathrm{M} \mathrm{Na} . \mathrm{SO}_{4} & 0.003 \mathrm{M} \mathrm{SO}_{4}=。\end{array}$

Secrat

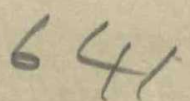

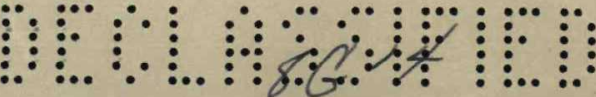



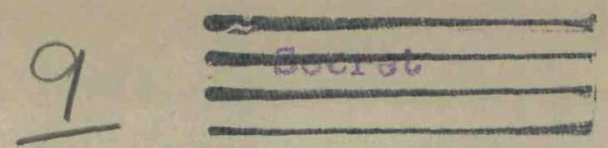

The first three $3 \theta$ tions of rable 4 ghow the variation of F with nitric acid and TFA concentrations. In a previous report CNe2486 it was reported that $\mathrm{E}$ followed f fourth power dependerce 3aw $E=\mathrm{K}$ (MFA)4: The points upon which this law was based could

$$
\text { (II) }
$$

not bo dupliseated since they were in a region where the shakine time was very critlcal. Tnasmuch as the true lit and TFA concentrations In the heterogeneous extrection system cannot be evaluated without further data, the true dependonce upon HNO 3 and TFA concentrations

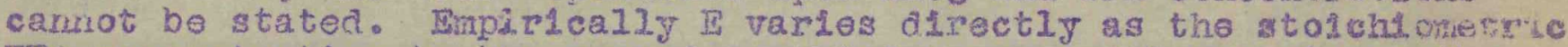
TFA concentration to the second or third power and 1 rversely as the

- third or fourth power of the stolchlometric Ho concentration.

In the fourth agction of Table 4 1t $1 \mathrm{~s}$ shown that the sul= fato compler with Pu(IV) is mch stronger than the Pu(IV) chelate complex for the extraction coefric Ients with NagSO, present are mueh lower than in the 1dent1cal axperiment periormed in the absence of Na $\mathrm{SO}_{4}$. In the last two sections, tho varlation in $E$ with UNH and UNH $\mathrm{Na}_{2} \mathrm{SO}_{4}$ mixtures 18 ghown. The dropping of $f$ of $\mathrm{E}$ with UMH was thought to be due to the effect of nitrate son complexing of Pu(IV). To substantiate this $1.6 \mathrm{M} \mathrm{NaNO}$ was bubstituted for $0.8 \mathrm{M}$ JM in one experiment. As may bo been $\mathrm{E}$ also dropped in the presence of $\mathrm{NaNO}_{3}$ but not as Iar as when tho comparable amount of UNH Was used. The entire effect of UINH upon the extraction coefficlent may st111 be due to nitrate fon as the discrepancy between the UNH and the NaNOS result may be due to a alfference in the lonic strength of the two solutions. The lonic strength cannot bo exactiy detexmined in the case of UMH bocause of tire possibl1ty of weal salt formation in the solution. In the presence of vo $e^{t}$ the marked effect of $\mathrm{Na}_{2} \mathrm{SO}_{4}$ upon the extractioi coefficient is greatly ilminished. It is bo lieved that the relatively syall lowering of the extraction coefficient

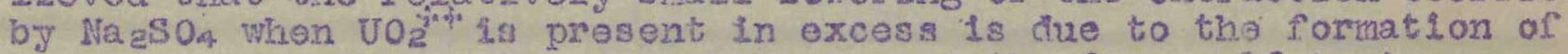
a uranyl sulfate complex Ion whlch lowerg the freo sulfate $10 n$ concen tration and correspondingly the extent of the Pu(IV) sulfate complaxln:。

From the results in Table 4 concltions can be selerted to obtain a range of desired extraction coefflcients neglecting the as jot undetemined effect of reduction of Pu(IV) by TFA. Shaking times of 15-20 minutes are required to achiove oquilibrium extraction. Re= sults reported in $C N=2486$ that conflict with values in Table 4 are due to uscontrolled shairing times. In most of those experiments. the sizaling times were of the order of 30 seconds so the extraction coefficlents aro much higher than the equilibrium valuos. The high values can be achleved, however, under equilibrium conditions by a relat1vely gmall increase in the TFA concentration.

In the immediate future experiments are plannod to study the reduction of Pu(IV) by TFA and to further study the decontanination pronerties of the process. 


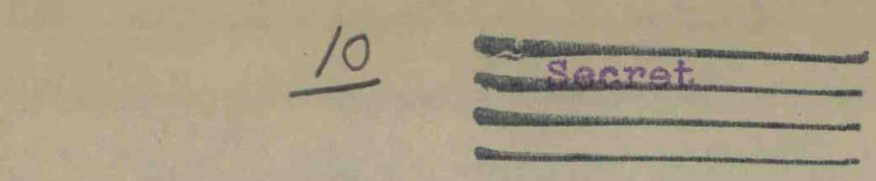

II. The Behavior of TFA In Water Solutions

James C. Reid

TFA is not stable in alkal1, belng hydrolyzed to acers tone and trifluoracetio scld. The reaction is moderately rapid; the ketone 1 s $80 \%$ hydrolyzed after fourteen hours standing in tenth normal alkal1 at room temperature.

TFA is stable in solutions of nitric, hydrochloric or sulfuric acid as concentrated as 0.5 momal. Highem concentrations have not beer quantitalively investigated, although it is known that the ketone can be steam distilled from $10 \%$ sulfurlc ac1d with at least $75 \%$ recovory.

Although TFA 18 recoverable quantite.tvely from acid golutions, 1t: appears to enter into an equilibrium with some substance, 2 s yet unidentifled, which is inerrective in tho extraction of Pu. This process is being investigated. 